\title{
Copper induces expression and methylation changes of early development genes in Crassostrea gigas embryos
}

\author{
Sussarellu Rossana ${ }^{1,{ }^{*}}$, Lebreton Morgane ${ }^{1,2}$, Rouxel Julien ${ }^{1}$, Akcha Farida ${ }^{1}$, Rivière Guillaume ${ }^{2}$ \\ ${ }^{1}$ Ifremer, Laboratoire d'Ecotoxicologie, Rue de l'lle d'Yeu, 44311 Nantes, France \\ ${ }^{2}$ UMR BOREA, Université Caen-Basse Normandie, Esplanade de la Paix, Caen 14032, France \\ * Corresponding author : Rossana Sussarellu, email address : rossana.sussarellu@ifremer.fr
}

\begin{abstract}
:
Copper contamination is widespread along coastal areas and exerts adverse effects on marine organisms such as mollusks. In the Pacific oyster, copper induces severe developmental abnormalities during early life stages; however, the underlying molecular mechanisms are largely unknown. This study aims to better understand whether the embryotoxic effects of copper in Crassostrea gigas could be mediated by alterations in gene expression, and the putative role of DNA methylation, which is known to contribute to gene regulation in early embryo development.
\end{abstract}

For that purpose, oyster embryos were exposed to 4 nominal copper concentrations $(0.1,1,10$ and $20 \mu \mathrm{g} \mathrm{L}^{-1} \mathrm{Cu}^{2+}$ ) during early development assays. Embryotoxicity was monitored through the oyster embryo-larval bioassay at the D-larva stage $24 \mathrm{~h}$ post fertilization (hpf) and genotoxicity at gastrulation 7 hpf. In parallel, the relative expression of 15 genes encoding putative homeotic, biomineralization and DNA methylation proteins was measured at three developmental stages (3 hpf morula stage, $7 \mathrm{hpf}$ gastrula stage, $24 \mathrm{hpf}$ D-larvae stage) using RT-qPCR. Global DNA content in methylcytosine and hydroxymethylcytosine were measured by HPLC and gene-specific DNA methylation levels were monitored using MeDIP-qPCR.

A significant increase in larval abnormalities was observed from copper concentrations of $10 \mu \mathrm{LL}^{-1}$, while significant genotoxic effects were detected at $1 \mu^{-1}$ and above. All the selected genes presented a stage-dependent expression pattern, which was impaired for some homeobox and DNA methylation genes (Notochord, HOXA1, HOX2, Lox5, DNMT3b and CXXC-1) after copper exposure. While global DNA methylation (5-methylcytosine) at gastrula stage didn't show significant changes between experimental conditions, 5-hydroxymethylcytosine, its degradation product, decreased upon copper treatment. The DNA methylation of exons and the transcript levels were correlated in control samples for HOXA1 but such a correlation was diminished following copper exposure. The methylation level of some specific gene regions (HoxA1, Hox2, Engrailed2 and Notochord) displayed changes upon copper exposure. Such changes were gene and exon-specific and no obvious global trends could be identified. Our study suggests that the embryotoxic effects of copper in oysters could involve homeotic gene expression impairment possibly by changing DNA methylation levels. 


\section{Highlights}

- Copper exposure induces embryotoxic and genotoxic effects in C. gigas embryos. Global DNA methylation levels were not significantly altered by copper exposure. Global levels of 5hydroxymethylcytosine decreased upon copper treatment. - Copper exposure disrupted the methylation of some homeobox genes. Copper disrupted the expression of some of some homeobox and DNA methylation genes.

Keywords : Oyster, Embryotoxicity, Copper, Gene expression, DNA methylation 


\section{Introduction}

Coastal waters are contaminated by a high diversity of chemical pollutants from various origins. Among them, copper is a historic pollutant, and as a consequence its contamination levels in the marine environment as well as its toxicity in marine organisms have been well investigated. Environmental copper concentrations in the French Atlantic coast between 2010 and 2015 were around 0.5-1.0 $\mu \mathrm{g} \cdot \mathrm{L}^{-1}$ in seawater (Guesdon et al., 2016), and 1-280 $\mu \mathrm{g} \cdot \mathrm{g}^{-1}$ in sediments (ROCCH, 2016). Nevertheless, copper concentrations over $1 \mu \mathrm{g} \cdot \mathrm{L}^{-1}$ are regularly recorded in harbours or bays, such as the Arcachon bay in France, which is also a shellfish production area, where concentrations up to $3.5 \mu \mathrm{g} . \mathrm{L}^{-1}$ were observed (Gamain et al., 2017). The level of contamination in bivalve flesh is continually growing since 1980. In 2015, the median concentration of copper in oysters was $216 \mathrm{mg} \mathrm{kg}^{-1}$ dry weight compared to $80 \mathrm{mg}^{\mathrm{kg}}{ }^{-1}$ in the 80 's $(\mathrm{ROCCH}, 2016)$. Pesticides/biocides are the prevalent uses of copper due to its anti-cryptogamic and anti-bacterial properties. Indeed, copper sulphate $\left(\mathrm{CuSO}_{4}\right)$ is used since $19^{\text {th }}$ century in agriculture as the "Bordeaux mixture". Moreover, copper oxide is used as a biocide in antifouling paints, especially since tributyltin ban in 2003.

Bivalve species are filter feeders and sessile and owning to these ecological characteristics, they are considered as sentinel species in environmental toxicology studies. Their sensitivity to copper is well known especially during early life stages. In oysters significant increases in larval abnormality percentages were observed from concentrations of $0.1 \mu \mathrm{g} . \mathrm{L}^{-1}$ (Mai et al., 2012). In ecotoxicology studies, the occurrence of larval malformations enables the evaluation of the toxicity of chemical substances or matrices through the standardized oyster or mussel embryo-toxicity test ISO17244:2015. This bioassay consists in counting the larval abnormalities in the first shelled-larvae stage, the D-larvae. The adverse effects of copper on oyster larvae are so potent that copper is used as a positive control in this bioassay. According to multiple studies, the $\mathrm{EC}_{50}$ of copper on oyster larvae is between 6 and $16 \mu \mathrm{g} \cdot \mathrm{L}^{-1}$ of $\mathrm{Cu}^{2+}($ ISO17244:2015). Moreover, copper induces genotoxicity on $C$. gigas larvae with an increase of DNA breaks from concentrations of $0.1 \mu \mathrm{g} \cdot \mathrm{L}^{-1}$ of $\mathrm{Cu}^{2+}$ (Mai et al., 2012). Anyway, despite the fact that the copper levels inducing developmental abnormalities in early life stages of the Pacific oyster are well known, the underlying molecular mechanisms remain unexplored.

Embryo development is determined by the spatial and temporal coordination of several genes. Alterations in gene expression during crucial embryo-larval steps can lead to developmental abnormalities and ultimately to death. According to the altered phenotypes observed upon copper 
exposure (shell and mantle abnormalities as well as development arrest), the malformations in C. gigas embryos likely involve impairment of the function of genes having a role in early development as well as in shell biomineralization. Many crucial genes for development of the Pacific oyster have been identified and characterized by orthology (Paps et al. 2015). Some biomineralization genes such as Collagen, Nacrein and Calcineurin B are essential for shell formation processes, including calcification regulation and calcium-dependent signal transduction (Miyamoto et al., 2005; Rusnak and Mertz, 2000). More recently, it has been shown that epigenetic regulation is an important regulator of $C$. gigas ontogenesis. Indeed, while global DNA methylation levels display variations during larval life, DNA methyltransferase inhibition induces major perturbations of oyster development (Riviere et al., 2013). Promoter DNA methylation of some early developmental genes has been shown to be inversely correlated to their transcript levels (Riviere et al., 2013; Saint-Carlier and Riviere, 2015). Because DNA methylation is known to depend on environmental factors (Feil \& Fraga, 2011; Vandegehuchte \& Janssen, 2014), epigenetic processes might participate in developmental impairments induced by contaminant exposure.

In this study we aimed to investigate the underlying molecular mechanisms responsible for larval abnormalities in C. gigas embryos exposed to copper. Larval abnormalities and genotoxic effects were investigated together with transcript levels of genes involved in early development, biomineralization and DNA methylation. We measured the global levels of hydroxy- and methylcytosine and used a targeted approach to examine whether larval abnormalities, gene expression, and DNA methylation could be associated.

\section{Material and Methods}

\section{Fertilization and experimental exposure}

Sexed mature oysters (Crassostrea gigas, Thunberg, 1793) came from the Guernsey Sea Farm commercial hatchery (UK). After reception, oysters were stored in seawater at $12^{\circ} \mathrm{C}$ with aeration. The seawater used in this study came from the experimental hatchery of Ifremer La Tremblade (France) and was filtered $(1 \mu \mathrm{m})$ and UV-treated with salinity of $27 \mathrm{PSU}$. The water was stored at $4^{\circ} \mathrm{C}$ and filtered once more at $0.22 \mu \mathrm{m}$ prior to use. Mature oysters were induced to spawn by thermal shock transferring them into a $29^{\circ} \mathrm{C}$ bath for $30 \mathrm{~min}$ to induce gamete release. Spawning individuals were then isolated in individual beakers and gametes were checked for oocyte shape and sperm motility under an inverted 
microscope. Oocytes and sperm were filtered on a $100 \mu \mathrm{m}$ and $40 \mu \mathrm{m}$ sieve, respectively, in order to eliminate debris. The oocytes were counted using a Thoma cell counting chamber and fertilization was started by adding spermatozoa (10 spermatozoa per oocyte). Within 30 min after mixing, polar body emission was observed under an inverted microscope in order to check fertilization success. Zygotes were then transferred to the different exposure conditions at a concentration of 50 embryos. $\mathrm{mL}^{-1}$ in $2 \mathrm{~L}$ glass jars filled with filtered seawater at $24^{\circ} \mathrm{C}$ and supplied with air bubbling. Five experimental conditions were set up, a seawater control and $4 \mathrm{CuSO}_{4}$ (Sigma-Aldrich) concentrations (nominal $\mathrm{Cu}^{2+}$ concentrations: $0.1 ; 1 ; 10$ and $\left.20 \mu \mathrm{g} \cdot \mathrm{L}^{-1}\right)$ with 4 replicates per condition.

\section{Embryo sampling}

Embryos were sampled at 3 hours post fertilization (hpf), $7 \mathrm{hpf}$, and $24 \mathrm{hpf}$. These sampling times correspond to the morula, gastrula and D-larva stages in control conditions, respectively. Four replicates consisting of $2 \mathrm{~L}$ glass jars per condition and sampling time (60 samples in total) were sieved on a 20 $\mu \mathrm{m}$ mesh in order to concentrate the embryos. Larvae (ca. 50000 per aliquot) were then pelleted by centrifugation at $100 \mathrm{~g}$ for $5 \mathrm{~min}$ at $4^{\circ} \mathrm{C}$. Pellets were re-suspended in $1.5 \mathrm{~mL}$ of TRI Reagent (Ambion), and then immediately frozen in liquid nitrogen for RNA extraction or directly snap-frozen in liquid nitrogen for DNA extraction. Samples were thawn only once before use. At the gastrula stage, 50000 larvae per replicate and condition (20 samples) from additional $2 \mathrm{~L}$ jars were sampled for the comet assay and 50000 for total DNA methylation. For embryotoxicity tests, 1500 D-larvae were collected at $24 \mathrm{hpf}$, directly in the $2 \mathrm{~L}$ jars prior to sieve and stored in a $0.1 \%$ seawater-formaldehyde solution for visual inspection.

\section{Embryotoxicity assay}

One hundred larvae per sample were analyzed under an Olympus CK40 inverted microscope $(\times 20$ magnification) in order to determine the proportion of abnormal larvae, i.e. those presenting shell and/or mantle deformities according to the standardized embryo-larval bioassay (ISO17244:2015, 2015; Quiniou et al., 2005).

\section{Comet assay}

Four replicates of gastrula pellets per condition (50000 larvae each) for a total of 20 samples, were washed in $2 \mathrm{~mL}$ of Calcium Magnesium Free Saline buffer (CMFS) (20 mM HEPES, 500 mMNaCl, 12.5 $\mathrm{mMKCl}, 5 \mathrm{mM}$ EDTA), and centrifuged at $650 \mathrm{~g}$ for $5 \mathrm{~min}$. Two $\mathrm{mL}$ of $0.25 \%$ Trypsin (Sigma-Aldrich) were then added to the pellet and gently agitated at room temperature for $3 \mathrm{~min}$. The cell suspension 
was sieved through $30 \mu \mathrm{m}$ Partec CellTrics and the cells were re-suspended in CMFS supplemented with $20 \%$ RPMI 1640 and 20\% SVF. After centrifugation (650 g, 5 min), the supernatant was discarded and the cell pellet directly resuspended in $160 \mu \mathrm{L}$ of $0.5 \%$ low-melting point agarose (LMP) in Phosphate Buffered Saline (PBS) (137 mMNaCl, $2.7 \mathrm{mMKCl}, \mathrm{pH}$ 7.4). The suspension was deposited over 2 glass slides previously coated with $0.5 \%$ normal melting point agarose (NMP) in PBS and spread using a micro-cover glass. Slides were immediately put on a cold tray in the dark in order to allow agarose to polymerize then a third layer of $80 \mu \mathrm{L}$ LMP was added. After agarose polymerization, slides were immersed in ice-cold lysis buffer $(2.5 \mathrm{M} \mathrm{NaCl}, 0.1 \mathrm{M}$ EDTA-Na2, $0.01 \mathrm{M}$ Tris base, $1 \% \mathrm{~N}$-sarcosinate, 1\% DMSO 10\%, Triton X-100 1\%, pH 10) and incubated in the dark at room temperature overnight. At the end of the lysis period, electrophoresis for $20 \mathrm{~min}$ at $13 \mathrm{~V}(390 \mathrm{~mA}, \mathrm{E}=0.66 \mathrm{~V} / \mathrm{cm})$ was performed. Slides were then washed in Tris base (0.4 M, pH 7.5) and fixed in absolute ethanol for $10 \mathrm{~min}$. Slides were dried overnight and stored at room temperature prior to analysis. Right before microscopic analysis, slides were stained with $75 \mu \mathrm{L}$ of Gel Red $\left(8 \mathrm{mg} \cdot \mathrm{L}^{-1}\right)$ and incubated at least an hour in the dark at $4^{\circ} \mathrm{C}$. Slides were observed under an optical fluorescence microscope (Olympus BX60, $\times 40$ ) equipped with a CCD camera (Luca-S, Andor Technology) and an image analysis system (Komet 6, Kinetic Imaging Ltd.). Fifty nuclei were analyzed per slide and the percentage of DNA present in the Comet tail (\%Tail DNA) was measured for each observed nucleus.

\section{Total DNA methylation}

One $\mathrm{mL}$ of lysis buffer (0.02 $\mathrm{M}$ Tris $\mathrm{pH} 8,0.1 \mathrm{M} \mathrm{NaCl}, 1 \mathrm{mM}$ EDTA, $0.5 \%$ SDS) was added to each of the 4 replicates of gastrula pellets per condition (50000 larvae each, 20 samples in total) and kept overnight at $55^{\circ} \mathrm{C}$ in the presence of $0.3 \mathrm{mg}$ of proteinase $\mathrm{K}$. DNA was extracted with phenol-chloroform (1 $\mathrm{mL})$ (ACRO Organics), isopropanol (Sigma-Aldrich) precipitated and quantified using a ND1000 NanoDrop. Global DNA methylation level was determined by UV-HPLC analysis according to the protocol of Armstrong et al. (2011) with some modifications as described in Bachère et al., (2017). For each sample, $5 \mu \mathrm{g}$ of DNA were digested by incubation with nuclease P1 (1.5 $\mathrm{U}$ per $\mu \mathrm{g} \mathrm{DNA})$ for $2 \mathrm{~h}$ at $37^{\circ} \mathrm{C}$ and alkaline phosphatase $(2.5 \mathrm{U}$ per $\mu \mathrm{DNNA})$ for an additional $1 \mathrm{~h}$ at $37^{\circ} \mathrm{C}$. After centrifugation (10 $\mathrm{min}, 7000 \times \mathrm{g}, 4^{\circ} \mathrm{C}$ ), the supernatant was recovered for analysis by HPLC coupled to UV detection (Agilent 1200 series). Separation of the deoxyribonucleosides was performed on a Phenomenex Security Guard ULTRA Cartridge UHPLC C18 pre-column and a PhenomenexKinetex 2.6 um C18 100A $100 \times 4.6 \mathrm{~mm}$ column. The column oven was set at $10^{\circ} \mathrm{C}$. Elution was performed in isocratic mode using 
a mobile phase composed of $50 \mathrm{mM}$ diammonium-hydrogenophosphate, and $3 \%$ acetonitrile, $\mathrm{pH} 4.1$. The elution flow rate was set at $1.3 \mathrm{~mL} \cdot \mathrm{min}^{-1}$ and the pressure in the system was 330 bars. Commercially available nucleotides (dAMP, dTMP, dGMP, dCMP, dUMP) were injected individually and in mixture (total injection volume of $13 \mu \mathrm{L}$ ) in order to determine their respective retention time following UV detection at $280 \mathrm{~nm}$. Standard curves were also generated for cytosine (dCMP: 0.5-2.0 nmoles), 5methylcytosine (5-mdC: $0.01-0.10$ nmoles) and 5-hydroxymethylcytosine (5-OHmdC: 0.02-0.15 nmoles). For each sample the $5-\mathrm{mdC} \%$ or $5-\mathrm{OHmdC} \%$ were calculated as follows: $5-\mathrm{mdCMP} \%=[5-$ $\mathrm{mdC} /(\mathrm{dCMP}+5-\mathrm{mdC})] \times 100$ or $5-\mathrm{OHmdC} \%=[5-\mathrm{OHmdCMP} / 5-\mathrm{mdC})] \times 100$. For the conditions described, run time was $10 \mathrm{~min}$ and the retention times for dCMP, 5-mdC and 5-OhmdC were 1.7, 2.4 and $0.9 \mathrm{~min}$, respectively.

\section{RNA extraction and Real-Time PCR}

Total RNA was isolated from 60 samples using TRI Reagent according to the manufacturer's instructions. RNA concentrations were determined using a ND-1000 spectrophotometer (ThermoScientific, Waltham MA, USA). RNA was treated with DNase I (Ambion, Life Technologies, 0.1 $\mathrm{U} \cdot$ per $\mu \mathrm{g}$ of RNA) following the manufacturer's instructions, and precipitated with isopropanol $(\mathrm{v} / \mathrm{v})$ and 0.3 M sodium acetate. RNA integrity was assessed on an Agilent bioanalyzer using RNA 6000 Nano kits (Agilent Technologies), according to the manufacturer's instructions, for a mean RNA Integrity Number (RIN) of $7.6 \pm 0.4$. Reverse transcription was carried out with the High-Capacity cDNA Reverse Transcription Kit (Applied Biosystems), according to the manufacturer's instructions on $1 \mu \mathrm{g}$ of total RNA.

The levels of 15 mRNA transcripts were measured by real-time PCR. Specific primers were designed using Primer 3 V 4.0.0 (Untergasser et al., 2012). Two reference genes were considered: glyceraldehyde-3-phosphate dehydrogenase (GAPDH) and elongation factor 1 alpha (EF1). The PCR efficiency $(E)$ was assessed for each primer pair on a sample containing cDNA from the three developmental stages by serial dilutions and was comprised between $83.5 \%<\mathrm{E}<107 \%$. The primers sequences and Genbank accession numbers for the genes considered are in the supplementary file SI 1a. Real-time PCR reactions ( $15 \mu \mathrm{L}$ final volume containing Roche LightCycler 480 Probes Master, SYBR Green, $0.05 \mu \mathrm{M}$ of each primer and cDNA diluted to $1 / 40$ ) were carried out in triplicate in 384wells microplates in a LightCycler 480 thermal cycler (Roche). Runs started with $5 \mathrm{~min}$ at $95^{\circ} \mathrm{C}$, followed by 45 cycles of $10 \mathrm{~s}$ at $95^{\circ} \mathrm{C}, 20 \mathrm{~s}$ at $60^{\circ} \mathrm{C}$ and $20 \mathrm{~s}$ at $72^{\circ} \mathrm{C}$. Accurate amplification of the target amplicon 
was checked by performing a melting curve. Each run included the cDNA inter-run control, a no-template control and a water control. The geometric mean of the two reference genes was used to normalize gene expression using the Pfaffl formula (Pfaffl, 2001) and specific amplification efficiencies.

\section{DNA extraction and MeDIP Real-Time PCR}

MeDIP Real-Time PCR was performed on samples from the control and $10 \mu \mathrm{g} \cdot \mathrm{L}^{-1}$ copper groups only, because this concentration is close to the determined $\mathrm{EC}_{50}$ value and considered as the most potent for the induction of both gene expression changes and larval abnormalities. DNA was extracted with Nucleospin Tissue Kit (Macherey-Nagel) according to manufacturer's instructions. Briefly, the DNA of 50000 larvae was extracted, purified by column affinity chromatography, washed with ethanol, and eluted in $5 \mathrm{mMTris} / \mathrm{HCl}, \mathrm{pH}$ 8.5. Extracted DNA was quantified by spectrometry (Nanodrop 2000, Thermo Scientific) and then $10 \mu \mathrm{g}$ were fragmented by sonication at $100 \mathrm{ng} \cdot \mu \mathrm{L}^{-1}$ in ultrapure water (10 pulses of 10 seconds in discontinuous mode, with cooling of 30 seconds on ice every three pulses on a VibraCell sonicator (Bioblock Scientific) at $40 \%$ power using a $2 \mathrm{~mm}$ diameter probe) in order to obtain ca. 500 bp fragments as assessed on 1\% agarose gel electrophoresis followed with ethidium bromide staining. Methylated DNA immunoprecipitation was performed using the MagMeDIP Kit (Diagenode) according to manufacturer's instructions. Briefly, $1.2 \mu \mathrm{g}$ of fragmented DNA was denatured 3 minutes at $95^{\circ} \mathrm{C}$. A DNA aliquot (ca. $100 \mathrm{ng}$, 'input' fraction) was saved at this point from each sample and stored at $4^{\circ} \mathrm{C}$ during immunoprecipitation of the 'IP' fraction. Fragmented DNA was immunoprecipitated ('IP' fraction) with an anti-5-methylcytosine monoclonal antibody (clone 33D3, Diagenode) coated on magnetic beads at $4^{\circ} \mathrm{C}$ overnight. Samples were extensively washed and recovered by retention on a magnetic rack. Potential remaining protein contamination (RNase) were removed with $1 \mathrm{U}$ proteinase $\mathrm{K}$ for 15 minutes at $55^{\circ} \mathrm{C}$, followed by inactivation at $100^{\circ} \mathrm{C}$ for 15 minutes. The immunoprecipitated DNA was eluted (IP DNA) and the 'Input' fraction diluted (Input DNA) in a final volume of $100 \mu \mathrm{L}$ using DIB buffer (Diagenode). Real time PCRs (15 $\mu \mathrm{L}$ final volume) were realized on $3 \mu \mathrm{L}$ Input and IP DNA with GoTaq qPCR Master Mix, (Promega) and gene-specific primers (0.3 $\mu \mathrm{M}$ each) using a CFX96 RealTime PCR Detection System (Bio-Rad). Cycling conditions were: 5 min at $95^{\circ} \mathrm{C}$ followed by 45 cycles of $10 \mathrm{~s}$ at $95^{\circ} \mathrm{C}, 40 \mathrm{~s}$ at $60^{\circ} \mathrm{C}$. Primers were designed to target potentially methylated $\mathrm{CpG}$ regions on exons within the HoxA1, Hox2, Engrailed 2 and Notochord genes. The primers' PCR efficiency ( $E$ ) was estimated for each primer pair using a 4-log dilution series of genomic DNA (0.05 to $50 \mathrm{ng}$ final concentration) pooled from the three developmental stages examined. The specificity of the 
immunoprecipitation was checked using $0 \%$ and $100 \%$ methylated DNA included in the samples. It corresponds to the proportion of methylated DNA enrichment in the IP fraction. Reactions were validated only for specificities above $95 \%$. The primer sequences, the number of $\mathrm{CpG}$ per amplified region and their localization in gene exons are given in SI $1 \mathrm{~b}$. The methylation level of each examined region is given by the ratio between the real-time PCR signal between the IP and Input fractions, IP/Input $=2^{\text {(Ct }}$ Input -Ct IP). Methylation levels are given relative to controls $(=1)$.

\section{Statistics}

Data were processed and analyzed using the language R/BioConductor, ( $R$ Development Core Team) (Gentry et al., 2004). "drc" package was employed to model the dose response curve with the Weibull 3 parameters model (Ritz et al., 2015). PCA analyses were performed with the "ade4" package analyses (Dray and Dufur, 2007). Normality and homogeneity of variance were tested on residuals using the Shapiro-Wilk test and Fligner test. Angular transformation was used for percentage data. One-way ANOVA and Least-significant difference post hoc tests were performed to discriminate groups if the homoscedasticity was observed; otherwise Kruskal-Wallis rank sum test was performed. Target DNA methylation data were normalized to control samples and further tested with Student's t-Test. $p$-values $<0.05$ were considered as significant.

\section{Results}

\section{Embryotoxicity and genotoxicity tests}

Copper caused increases in C. gigas larval abnormalities with an $\mathrm{EC}_{50}$ value of $9.1 \mu \mathrm{g} . \mathrm{L}^{-1}$ (Figure 1a). A Significant rise in embryo-larval abnormalities was recorded starting from $10 \mu \mathrm{g} \cdot \mathrm{L}^{-1}$ of $\mathrm{Cu}^{2+}$ (ANOVA pvalue $<0.001)$. Given the low percentage $(16 \pm 5 \%)$ of larval abnormalities in control conditions as well as the $\mathrm{EC}_{50}$ value between 6 and $16 \mu \mathrm{g} \cdot \mathrm{L}^{-1}$, the embryo-larval test was validated according to the criteria given by the standardized test (ISO17244:2015). At the highest concentration (20 $\left.\mu \mathrm{g} \cdot \mathrm{L}^{-1} \mathrm{Cu}^{2+}\right)$, most of the observed abnormalities were shell abnormalities and $10 \%$ of the individuals presented a developmental arrest (Figure 1b). The comet assay revealed a significant increase in DNA strand breaks in gastrula embryos from $1 \mu \mathrm{g} \cdot \mathrm{L}^{-1}$ of $\mathrm{Cu}^{2+}$ (ANOVA p-value<0.001, Figure 2).

\section{Global DNA Methylation}


Global DNA methylation levels (5-Methylcytosine) were not significantly affected by the different experimental conditions (Fig. 3a). The level of 5-Hydroxymethyl-deoxycytosine was significantly decreased upon exposure at the highest tested copper concentration (ANOVA p-value $<0.05$, Fig. 3b).

\section{Gene expression analysis}

The PCA analysis of gene expression clearly indicates that developmental stages are associated with specific transcript patterns (components 1 and 2 accounted for $48.47 \%$ and $29.76 \%$ of the variance, respectively) and underline the implication of the genes examined in the different stages of oyster development (Figure 4). Six of those genes have their mRNA level influenced by copper exposure (Figure 5) while the expression of the other 9 is not significantly affected by the treatment (SI 2). At the morula stage, Notochord was the only gene examined whose transcription was significantly increased in copper-exposed oysters when compared to controls $(p=0.03)$. In gastrulas, Notochord $(p=0.01)$, HOXA1 $(p=0.006)$ and HOX2 $(p=0.04)$ displayed a concentration-dependent decrease in their mRNA expression regarding copper concentration. In contrast, $C X X C-1$ transcript levels were significantly increased at the highest copper concentration $(p=0.04)$. At the $D$-larvae stage, for the $20 \mu \mathrm{g} \cdot \mathrm{L}^{-1}$ copper concentration Lox5 expression was increased $(p=0.04)$, whereas DNMT3 transcripts decrease $(p=$ 0.05) compared to control samples.

\section{Targeted analysis of DNA methylation}

The DNA methylation levels of the exons of 4 genes were investigated by Me-DIP Real-Time PCR in samples exposed to $10 \mu \mathrm{g} \cdot \mathrm{L}^{-1}$ of copper relative to controls. HoxA1, Hox2 and Notochord were differentially expressed upon copper exposure, while Engrailed2 was not. HoxA1 was chosen to investigate the relationship between expression and methylation levels during oyster development. A strong positive correlation was observed between the transcript level and the level of DNA methylation of the first exon in control samples $(r=0.93, p=2.7 e-05)$. This correlation was disrupted in samples exposed to copper $(r=0.58, p=0.04)$ (Figure 6$)$. The majority of changes in DNA methylation of HoxA1 induced by copper exposure of embryos were detected at gastrula stage (Figure 7a). Modifications in the methylation level were not consistent between exons with a decrease for exon 1 and an increase for exon 2. Hox2 presented a global increase of DNA methylation in all studied regions at the gastrula stage, albeit significantly only on exon 1 (Figure $7 \mathrm{~b}$ ). Notochord showed a high variability of DNA methylation levels in the 2 studied regions at morula stages (Figure 7c). Engrailed 2 did not display significant 
changes in methylation, but showed a weak global trend similar to HoxA1 at the gastrula stage (Figure $7 d)$.

\section{Discussion}

The main objective of this study was to contribute to the identification of some of the molecular mechanisms involved in larval abnormalities of oyster induced by copper contamination. Because oyster larvae are highly sensitive to copper, this metal trace element has become a positive control for embryotoxicity tests and is therefore a good model for studying the underlying pathways. The $\mathrm{EC}_{50}$ values for larval abnormalities herein $\left(9.1 \mu \mathrm{g} \cdot \mathrm{L}^{-1} \mathrm{Cu}^{2+}\right)$ are similar to those of former studies that range from 7.35 (Gamain et al., 2015) to $12.5 \mathrm{Cu}^{2+}$ (Mai et al., 2012).The slight differences in concentrations at which significant increases of abnormalities are detected between experiments may be explained by several factors. First, copper might be naturally present in the seawater used for the conduction of the bioassays at non-negligible concentrations (Gamain et al., 2015). In addition, a decreased salinity increases abnormalities, thereby lowering the $\mathrm{EC}_{50}$ as demonstrated by Gamain et al., (2015). Furthermore, DOM, and especially humic acids, can exert protective effects by complexing copper ions as shown in several models (De Schamphelaere et al., 2004; Knezovich et al., 1981; Lorenzo et al., 2002). Besides, the bioavailability of copper depends on the tested larval concentration (Franklin et al., 2002), and some studies may not comply to the normative guidelines of $20-50$ embryo. $\mathrm{mL}^{-1}$ with some impact on the observed embryotoxicity. Finally the broodstock origin can have an influence as demonstrated by Gamain et al.(2016), native wild oysters being more sensitive. Therefore, even though many parameters can influence the percentage of observed larvae abnormalities and explain small discrepancies between studies, the effect of copper is highly reproducible and its embryotoxicity remains within a comparable range among experiments.

Although copper is a trace element essential for a normal functioning of cells, high concentrations may catalyze the formation of reactive oxygen species potentially leading to oxidative stress (Balamurugan and Schaffner, 2006), which in turn induces damages to cellular macromolecules such as nucleic acids. The comet assay has widely been used to estimate the potential genotoxic effects of pollutants on aquatic organisms (Frenzilli et al., 2009). Mai et al (2012) found a significant increase in the DNA breaks when oyster larvae were exposed to $0.1 \mu \mathrm{g} \cdot \mathrm{L}^{-1}$ of copper, a concentration also leading to increased 
larval abnormalities. In our study, significant genotoxic effects were observed at lower concentrations (1 $\left.\mu g \cdot \mathrm{L}^{-1}\right)$ than those required to induce embryotoxicity, suggesting that oxidative damage to DNA might be an earlier marker of larval abnormalities as already suggested for organic pollutants (Wessel et al., 2007). Such an apparent discrepancy likely reflects the onset of compensatory mechanisms, which counteract the toxicity of $\mathrm{Cu}$ up to threshold concentrations above which the exposure cannot be physiologically managed thereby leading to larval abnormalities. Metal-induced oxidative stress is also known to affect DNA through epigenetic changes (Vandegehuchte and Janssen, 2011). For example, when exposed to copper, zinc, lead, cadmium or a metal mixture, the goldfish Carassius auratus showed increased DNA methylation levels in the liver (Xinwen et al., 2001). Furthermore, the ability of methyltransferases to interact with DNA may be affected by oxidative DNA damage thus resulting in a generalized altered methylation of CpG sites (Baccarelli and Bollati, 2009). Because methylation is a main factor driving gene expression, alterations of the genome structure such as DNA strand breaks could lead to epigenetic and transcriptional changes. Copper homeostasis in eukaryotes is directly linked to metal response element (MRE) at the promoter level of transcription factors regulating the metallothionein expression (Balamurugan and Schaffner, 2006). The presence of a MRE-binding transcription factor has been highlighted in $C$. gigas and its mRNA level was increased in a concentration-dependent manner upon cadmium exposure, activating metallothionein gene transcription (Qiu et al., 2013). However, the putative promoter regions of homeobox genes do not display any consensus MRE region in the present assembly of the oyster genome. Therefore such MREmediated transcriptional regulation unlikely participates to the expression pattern disruptions observed here. However, caution should be taken because of the lack of precision in promoter prediction in the present version of oyster genome (Riviere et al., 2015; Saint-Carlier and Riviere, 2015).

Gene expression was examined for genes involved in development (homeobox genes), shell biomineralization and DNA methylation, as potential candidates mediating larval abnormalities. As already demonstrated in C. gigas, severe phenotypic alterations of embryo development occur in the presence of a DNA methylation inhibitor in association with the disruption of function of homeobox and methylation genes (Riviere et al., 2013). The examined genes all showed an expression pattern strongly dependent on developmental stage. The expression pattern of some genes present a strong heterogeneity in some cases, possibly as the result of their acute and localized expression (Zhang et al., 2012). Thus, sampling duration, rate of cellular divisions and mismatched synchronization of 
embryos during the first hours, could create a shift in the expression peak of some genes. Furthermore, performing RNA extractions on large pools of larvae may mask some individual effects because of interindividual variability. The temporal coordination of homeobox genes is fundamental for a proper embryo development in many species, and has recently been described in C. gigas (Paps et al., 2015; Zhang et al., 2012). The expression of oyster homeobox genes peaks either during early development (egg to gastrula) or in late development after the trochophore larval stage (Paps et al. 2015). Here, 5 out of the 15 genes studied had their expression peak at the morula and 7 at the gastrula stage. Copper exposure was highly potent in inducing changes in expression of homeobox genes, especially at the gastrula stage. A global concentration-dependent decrease in the transcripts of Notochord, HOXA1, and HOX2 was observed at this stage at a copper concentration starting from $1 \mu \mathrm{g} \cdot \mathrm{L}^{-1}$, which corresponds to environmental values often recorded in coastal areas near or within estuaries or bays bearing shellfish production (Gamain et al., 2017). In contrast, an increased transcription was observed for Notochord at the morula stage and for Lox5 at the D-larvae stage for higher copper concentrations. Nevertheless, when considering the highly precise temporal and spatial pattern of homeobox gene expression (see SI 3, data from GigaTON Database, Riviere et al., 2015), the observed disrupting effects of copper exposure on their mRNA level might disturb developmental processes. Therefore, copper-induced stress may delay, disrupt and/or arrest the development, although a higher sampling frequency would be required to precisely determine whether the measured mRNA levels reflect a shift in the developmental kinetics rather than an overall copper-induced alteration in the expression of the observed genes.

Hox genes are transcription factors regulating the downstream expression of a great number of developmental genes encoding homeodomain-containing transcription factors that control the anterioposterior body axis patterning of animals. Because the regulatory mechanisms shared between species are considered conserved during animal evolution, mollusks, which belong to Lophotrochozoans, are often included in studies that discuss the origin of the metazoan body plan (Xu et al., 2016). Molluscan Hox gene orthologues are related to the activation of genes involved in shell formation (Jackson and Degnan, 2016), as suggested by the studies reporting their spatio-temporal expression pattern. In $C$. gigas, Notochord expression peaks at the blastula stage extending until early gastrula (see SI 3). In the closest phylogenetically studied species, the brachiopod Terebratalia transversa, Notochord is expressed from the early gastrula stage until completion of larval development (Altenburger et al., 2011) 
in the area of the apical lobe, which corresponds to the region that bears the cilia used for swimming. Considering a putative conserved role of developmental gene orthologues in closely related species, a disruption in Notochord expression might lead to a disrupted rotatory movement in early swimming stages of oyster. In C. gigas, expression peak of HOXA1 occurred at early gastrula, while $H O X 1$ transcripts in the gastropod Gibbula varia were localized in the shell field at the trocophore stage (10 hpf) (Samadi and Steiner, 2009). HOX1 is known to be involved in patterning of the shell field in a range of mollusks, being clearly expressed in cells associated with the shell field at 7hpf in Haliotis asinine prior to the transcription of downstream shell-forming genes (Jackson and Degnan, 2016). Consistently, disruption in expression of HOXA1 and HOX2 in this study could lead to perturbation of the shell formation process. Thus, in line with the observed shell abnormalities, the disrupted expression pattern of those genes, chosen by orthology, support their role in the molecular mechanisms involved in copper embryotoxicity. Nonetheless, it has to be considered that only transcript levels were measured here, and more studies are needed to fully understand the influence on the actual gene product which also involves posttranscriptional regulation that was not examined here.

DNA methylation is fundamental for a proper early embryo development in C. gigas and acute embryo abnormalities were observed in the presence of DNA methylation inhibitors (Riviere et al., 2013). It has been demonstrated that genome-wide methylation dynamics are major regulators of oyster early life through the control of development gene expression, as demonstrated using both a targeted approach on some Hox genes (Saint-Carlier and Riviere, 2015) and a genome-wide methodology (Riviere et al., 2017). If global DNA methylation varies strongly during the different stages of embryo development in C. gigas embryos (Riviere et al., 2013), we did not observe global 5-mdC content variations upon copper exposure at gastrula stage. Therefore we hypothesized that the observed disrupted expression of early expressed genes in copper-exposed embryos, and especially of homeotic genes, could be linked to DNA methylation disruption at their locus. Here, differences in $C X X C 1$ and DNMT3b transcript levels were observed for the highest copper concentration. Both are oyster orthologues of genes encoding proteins involved in the DNA methylation machinery: $C X X C 1$ binds to methyl-DNA and DNMT3b is the de novo DNA methyltransferase. Although copper induced alterations in the expression of DNA methylation regulators, we did not observe changes in the DNA methylation level at the global scale. Nevertheless, variations in the 5-mdC content of some targeted loci were reflected by our MeDIP-qPCR results (see below). Therefore alteration by copper exposure of $C X X C 1$ and DNMT3b expression is 
consistent with changes in DNA methylation at precise loci and their possible transcriptional outcomes. Inversely, demethylation in mammals is promoted by Tet 1 , which oxidizes $5-\mathrm{mdC}$ into $5-\mathrm{OHmdC}$ in a $\mathrm{Fe}^{2+}$ and alpha-ketoglutarate-dependent manner (Tahiliani et al., 2009). In this study no Tet 1 oyster orthologue mRNA level modification was detected, although copper induced a decrease in global 5OHmdC content. It is possible that the presence of high $\mathrm{Cu}^{2+}$ concentrations interferes with the irondependent catalytic activity of a putative Tet 1 in the oyster thereby explaining the decrease in $5-\mathrm{OHmdC}$ in exposed embryos. Altogether, through altered DNA methyltransferase transcription, transcript content of the gene encoding methyl-DNA binding protein, or catalytic activity of the product of Tet 1 , these results likely explain changes in the methylation pattern at precise loci. Such changes may partly be responsible for shifts in the expression pattern of development genes, especially because they occur at loci including 5 ' regions (putative promoter and/or first exons) of developmental genes. Indeed, the role of promoter methylation on C. gigas developmental gene expression has been demonstrated (SaintCarlier and Riviere, 2015). In addition, CpG methylation occurs mainly on exons and a positive correlation between exon methylation and gene expression has been demonstrated in adult oyster tissues (Olson and Roberts, 2014; Wang et al., 2014). In this study we show that HOXA1 first exon methylation was positively correlated with HOXA1 transcript levels in control conditions, while such correlation was decreased when embryos were exposed to $10 \mu \mathrm{g} \cdot \mathrm{L}^{-1}$ of copper. This clearly suggests that methylation participates or reflects epigenetic mediation of copper-induced transcriptional response involved in larval abnormalities. Yet, the methylation changes observed in copper-exposed conditions compared to control ones, were different between genes and even between exons within a gene and no global trend could be identified. Our results indicated the possibility of expression changes without methylation changes (as for Notochord), and conversely, methylation changes without expression changes (as for Engrailed 2). These mismatches reflect a high complexity of methylation regulation at the gene scale and prompt caution in the interpretation of methylation outcomes regarding gene expression. Consistent with recent hypotheses (Riviere et al., 2017), abnormal methylation could indeed disrupt the accessibility to regulatory sequences for the transcription machinery thereby mediating transcription activation/inhibition. Such effects could be the result of chromatin remodeling (Castellano et al., 2006). However, molecular mechanisms linking methylation to expression remain unclear in distant organisms. Many questions remain open regarding the molecular pathways involved in embryolarval defects due to contaminant exposure. Although this study brings evidence that epigenetic changes 
are associated to alteration in development gene transcription. Nonetheless, as stated above, other mechanisms could play a role in causing larval abnormalities and additional work on various chemicals coupling genome-, transcriptome- and epigenome-wide analyses is required to gain more insights into these mechanisms.

\section{Conclusions}

This study brings transcriptional and epigenetic data on molecular mechanisms involved in larval abnormalities induced by copper in oyster early life stages. Embryotoxic effects were observed from 10 $\mu \mathrm{g} \cdot \mathrm{L}^{-1}$ of $\mathrm{Cu}^{2+}$ and genotoxic effects at even lower concentrations $\left(1 \mu \mathrm{g} \cdot \mathrm{L}^{-1}\right)$ confirming the sensitivity of C. gigas embryos to copper. Early expressed genes including homeotic genes had their expression pattern disrupted by copper exposure. Moreover, global DNA methylation was not significantly modified by copper exposure, whereas $5-\mathrm{HOmdC}$ levels decreased at high copper concentrations. Nevertheless, specific DNA methylation changes in copper-exposed conditions were observed in targeted regions and differed between genes and between exons. This indicates that even if global methylation is not changed, the methylation of specific genes varies and is correlated to the gene expression. Altogether our results suggest that local changes in DNA methylation of developmental genes participate in expression impairment associated to the embryotoxic effect of copper in oyster larvae. This study brings new insights into the identification of functional early markers and their role in the embryotoxic effects of pollutant in C. gigas, a widespread marine sentinel species.

\section{Acknowledgements}

The authors would like to thank the GenoBiRD Genomic core facility of Nantes.

\section{Funding}

This work was supported by French national program EC2CO-Ecodyn (GANEsH). The internship to M. Lebreton was funded by French National Research Agency (ANR) as part of the Investments for the Future program within the Cluster of Excellence COTE (ANR-10-LABX-45). 


\section{References}

Altenburger, A., Martinez, P., Wanninger, A., 2011. Homeobox gene expression in Brachiopoda: The role of Not and $\mathrm{Cdx}$ in bodyplan patterning, neurogenesis, and germ layer specification, Gene Expression Patterns. doi:10.1016/j.gep.2011.07.001

Armstrong, K.M., Bermingham, E.N., Bassett, S.A., Treloar, B.P., Roy, N.C., Barnett, M.P.G., 2011. Global DNA methylation measurement by HPLC using low amounts of DNA. Biotechnol. J. 6, 113-7. doi:10.1002/biot.201000267

Baccarelli, A., Bollati, V., 2009. Epigenetics and environmental chemicals. Curr. Opin. Pediatr. 21, $243-251$. doi:10.1097/MOP.0b013e32832925cc

Bachère, E., Barranger, A., Bruno, R., Rouxel, J., Menard, D., Piquemal, D., Akcha, F., 2017. Parental diuronexposure alters offspring transcriptome and fitness in Pacific oyster Crassostrea gigas. Ecotoxicol. Environ. Saf. 142, 51-58. doi:10.1016/j.ecoenv.2017.03.030

Balamurugan, K., Schaffner, W., 2006. Copper homeostasis in eukaryotes: teetering on a tightrope. Biochim. Biophys. Acta 1763, 737-46. doi:10.1016/j.bbamcr.2006.05.001

Castellano, R., Vire, B., Pion, M., Quivy, V., Olive, D., Hirsch, I., Van Lint, C., Collette, Y., 2006. Active transcription of the human FASL/CD95L/TNFSF6 promoter region in T lymphocytes involves chromatin remodeling: role of DNA methylation and protein acetylation suggest distinct mechanisms of transcriptional repression. J. Biol. Chem. 281, 14719-28. doi:10.1074/jbc.M602373200

De Schamphelaere, K.A.C., Vasconcelos, F.M., Tack, F.M.G., Allen, H.E., Janssen, C.R., 2004. Effect of dissolved organic matter source of an acute copper toxicity to Daphnia magna. Environ. Toxicol. Chem. 23 , 1248. doi:10.1897/03-184

Dray, S., Dufur, A.-B., 2007. The ade4 package: Implementing the duality diagram for ecologists. J. Stat. Softw. $22,1-20$.

Feil, R., Fraga, M.F., 2011. Epigenetics and the environment: emerging patterns and implications. Nat. Rev. Genet. 13, 97-109. doi:10.1038/nrg3142

Franklin, N.M., Stauber, J.L., Apte, S.C., Lim, R.P., 2002. Effect of initial cell density on the bioavailability and toxicity of copper in microalgal bioassays. Environ. Toxicol. Chem. 21, 742-751. doi:10.1002/etc.5620210409

Frenzilli, G., Nigro, M., Lyons, B.P., 2009. The Comet assay for the evaluation of genotoxic impact in aquatic environments. Mutat. Res. Mutat. Res. 681, 80-92. doi:10.1016/j.mrrev.2008.03.001

Gamain, P., Cachot, J., Gonzalez, P., Budzinski, H., Gourves, P.-Y., Morin, B., 2017. Do Temporal and Spatial Parameters or Lifestyle of the Pacific Oyster Crasssostrea gigas Affect Pollutant Bioaccumulation, Offspring Development, and Tolerance to Pollutants? Front. Mar. Sci. 4, 58. doi:10.3389/fmars.2017.00058

Gamain, P., Gonzalez, P., Cachot, J., Clérandeau, C., Mazzella, N., Gourves, P.Y., Morin, B., 2016. Combined effects of temperature and copper and S-metolachlor on embryo-larval development of the Pacific oyster, Crassostrea gigas. Mar. Pollut. Bull. doi:10.1016/j.marpolbul.2016.12.018 
Gamain, P., Gonzalez, P., Cachot, J., Pardon, P., Tapie, N., Gourves, P.Y., Budzinski, H., Morin, B., 2015. Combined effects of pollutants and salinity on embryo-larval development of the Pacific oyster, Crassostrea gigas. Mar. Environ. Res. 113, 31-38. doi:10.1016/j.marenvres.2015.11.002

Gentry, J., Hornik, K., Hothorn, T., Huber, W., lacus, S., Irizarry, R., Leisch, F., Li, C., Maechler, M., Rossini, A., Gentleman, R., Sawitzki, G., Smith, C., Smyth, G., Tierney, L., Yang, J., Zhang, J., Carey, V., Bates, D., Bolstad, B., Dettling, M., Dudoit, S., Ellis, B., Gautier, L., Ge, Y., 2004. Bioconductor: open software development for computational biology and bioinformatics. Genome Biol. 5, R80. doi:10.1186/gb-2004-5$10-r 80$

Guesdon, S., Stachowski-Haberkorn, S., Lambert, C., Beker, B., Brach-Papa, C., Auger, D., Béchemin, C., 2016. Effect of local hydroclimate on phytoplankton groups in the Charente estuary. Estuar. Coast. Shelf Sci. 181, 325-337. doi:10.1016/j.ecss.2016.08.035

ISO17244:2015, 2015. Qualité de l'eau - Détermination de la toxicité d'échantillons aqueux sur le développement embryo-larvaire de l'huître creuse (Crassostrea gigas) et de la moule (Mytilus edulis ou Mytilus galloprovincialis).

Jackson, D.J., Degnan, B.M., 2016. The importance of evo-devo to an integrated understanding of molluscan biomineralisation. J. Struct. Biol. 196, 67-74. doi:10.1016/j.jsb.2016.01.005

Knezovich, J.P., Harrison, F.L., Tucker, J.S., 1981. The influence of organic chelators on the toxicity of copper to embryos of the pacific oyster, Crassostrea gigas. Arch. Environ. Contam. Toxicol. 10, 241-249. doi:10.1007/BF01055625

Lorenzo, J.., Nieto, O., Beiras, R., 2002. Effect of humic acids on speciation and toxicity of copper to Paracentrotus lividus larvae in seawater. Aquat. Toxicol. 58, 27-41. doi:10.1016/S0166-445X(01)00219-3

Mai, H., Cachot, J., Brune, J., Geffard, O., Belles, A., Budzinski, H., Morin, B., 2012. Embryotoxic and genotoxic effects of heavy metals and pesticides on early life stages of Pacific oyster (Crassostrea gigas). Mar. Pollut. Bull. 64, 2663-70. doi:10.1016/j.marpolbul.2012.10.009

Miyamoto, H., Miyoshi, F., Kohno, J., 2005. The carbonic anhydrase domain protein nacrein is expressed in the epithelial cells of the mantle and acts as a negative regulator in calcification in the mollusc Pinctada fucata. Zoolog. Sci. 22, 311-5. doi:10.2108/zsj.22.311

Olson, C.E., Roberts, S.B., 2014. Genome-wide profiling of DNA methylation and gene expression in Crassostrea gigas male gametes. Front. Physiol. 5, 224. doi:10.3389/fphys.2014.00224

Paps, J., Xu, F., Zhang, G., Holland, P.W.H., 2015. Reinforcing the egg-timer: recruitment of novel lophotrochozoa homeobox genes to early and late development in the pacific oyster. Genome Biol. Evol. 7, 677-88. doi:10.1093/gbe/evv018

Pfaffl, M.W., 2001. A new mathematical model for relative quantification in real-time RT-PCR. Nucleic Acids Res. 29. doi:10.1093/nar/29.9.e45

Qiu, J., Liu, Y., Yu, M., Pang, Z., Chen, W., Xu, Z., 2013. Identification and functional characterization of MREbinding transcription factor (MTF) in Crassostrea gigas and its conserved role in metal-induced response. Mol. Biol. Rep. 40, 3321-3331. doi:10.1007/s11033-012-2407-0 
Quiniou, F., His, E., Delesmont, E., Caisey, X., 2005. Bio-indicateur de la toxicité potentielle de milieux aqueux: bio-essai, Quae. ed.

Ritz, C., Baty, F., Streibig, J.C., Gerhard, D., 2015. Dose-Response Analysis Using R. PLoS One 10, e0146021. doi:10.1371/journal.pone.0146021

Riviere, G., He, Y., Tecchio, S., Crowell, E., Gras, M., Sourdaine, P., Guo, X., Favrel, P., Bird, A., Nakayama, A., 2017. Dynamics of DNA methylomes underlie oyster development. PLOS Genet. 13, e1006807. doi:10.1371/journal.pgen.1006807

Riviere, G., Klopp, C., Ibouniyamine, N., Huvet, A., Boudry, P., Favrel, P., 2015. GigaTON: an extensive publicly searchable database providing a new reference transcriptome in the pacific oyster Crassostrea gigas. BMC Bioinformatics 16, 401. doi:10.1186/s12859-015-0833-4

Riviere, G., Wu, G.-C., Fellous, A., Goux, D., Sourdaine, P., Favrel, P., 2013. DNA Methylation Is Crucial for the Early Development in the Oyster C. gigas. Mar. Biotechnol. 15, 739-753. doi:10.1007/s10126-013-9523-2

$\mathrm{ROCCH}, 2016$. Français, Les contaminants chimiques dans les huîtres et les moules du littoral [WWW Document]. URL http://envlit.ifremer.fr/surveillance/contaminants_chimiques

Rusnak, F., Mertz, P., 2000. Calcineurin: form and function. Physiol. Rev. 80, 1483-521.

Saint-Carlier, E., Riviere, G., 2015. Regulation of Hox orthologues in the oyster Crassostrea gigas evidences a functional role for promoter DNA methylation in an invertebrate. FEBS Lett. 589, 1459-66. doi:10.1016/j.febslet.2015.04.043

Samadi, L., Steiner, G., 2009. Involvement of Hox genes in shell morphogenesis in the encapsulated development of a top shell gastropod (Gibbula varia L.). Dev. Genes Evol. 219, 523-530. doi:10.1007/s00427-009-0308-6

Tahiliani, M., Koh, K.P., Shen, Y., Pastor, W.A., Bandukwala, H., Brudno, Y., Agarwal, S., Iyer, L.M., Liu, D.R., Aravind, L., Rao, A., 2009. Conversion of 5-Methylcytosine to 5-Hydroxymethylcytosine in Mammalian DNA by MLL Partner TET1. Science (80-. ). 324.

Untergasser, A., Cutcutache, I., Koressaar, T., Ye, J., Faircloth, B.C., Remm, M., Rozen, S.G., 2012. Primer3-new capabilities and interfaces. Nucleic Acids Res. 40, e115-e115. doi:10.1093/nar/gks596

Vandegehuchte, M.B., Janssen, C.R., 2014. Epigenetics in an ecotoxicological context. Mutat. Res. Genet. Toxicol. Environ. Mutagen. 764-765, 36-45. doi:10.1016/j.mrgentox.2013.08.008

Vandegehuchte, M.B., Janssen, C.R., 2011. Epigenetics and its implications for ecotoxicology. Ecotoxicology 20, 607-24. doi:10.1007/s10646-011-0634-0

Wang, X., Li, Q., Lian, J., Li, L., Jin, L., Cai, H., Xu, F., Qi, H., Zhang, L., Wu, F., Meng, J., Que, H., Fang, X., Guo, X., Zhang, G., 2014. Genome-wide and single-base resolution DNA methylomes of the Pacific oyster Crassostrea gigas provide insight into the evolution of invertebrate CpG methylation. BMC Genomics 15, 1119. doi:10.1186/1471-2164-15-1119

Wessel, N., Rousseau, S., Caisey, X., Quiniou, F., Akcha, F., 2007. Investigating the relationship between embryotoxic and genotoxic effects of benzo[a]pyrene, 17alpha-ethinylestradiol and endosulfan on 
Crassostrea gigas embryos. Aquat. Toxicol. 85, 133-42. doi:10.1016/j.aquatox.2007.08.007

Xinwen, Z., Guonian, Z., J, M., Jinhe, S., 2001. Influence of Cu, Zn, Pb, Cd and their heavy metalion mixture on the DNA methylation level of the fish (Carassius auratus). Zhongguo Huanjing Kexue 21, 549-552.

Xu, F., Domazet-Lošo, T., Fan, D., Dunwell, T.L., Li, L., Fang, X., Zhang, G., 2016. High expression of new genes in trochophore enlightening the ontogeny and evolution of trochozoans. Sci. Rep. 6, 34664.

doi:10.1038/srep34664

Zhang, G., Fang, X., Guo, X., Li, L., Luo, R., Xu, F., Yang, P., Zhang, L., Wang, X., Qi, H., Xiong, Z., Que, H., Xie, Y., Holland, P.W.H., Paps, J., Zhu, Y., Wu, F., Chen, Y., Wang, J., Peng, C., Meng, J., Yang, L., Liu, J., Wen, B., Zhang, N., Huang, Z., Zhu, Q., Feng, Y., Mount, A., Hedgecock, D., Xu, Z., Liu, Y., Domazet-Lošo, T., Du, Y., Sun, X., Zhang, S., Liu, B., Cheng, P., Jiang, X., Li, J., Fan, D., Wang, W., Fu, W., Wang, T., Wang, B., Zhang, J., Peng, Z., Li, Y., Li, N., Wang, J., Chen, M., He, Y., Tan, F., Song, X., Zheng, Q., Huang, R., Yang, H., Du, X., Chen, L., Yang, M., Gaffney, P.M., Wang, S., Luo, L., She, Z., Ming, Y., Huang, W., Zhang, S., Huang, B., Zhang, Y., Qu, T., Ni, P., Miao, G., Wang, J., Wang, Q., Steinberg, C.E.W., Wang, H., Li, N., Qian, L., Zhang, G., Li, Y., Yang, H., Liu, X., Wang, J., Yin, Y., Wang, J., 2012. The oyster genome reveals stress adaptation and complexity of shell formation. Nature 490, 49-54.

doi:10.1038/nature11413 


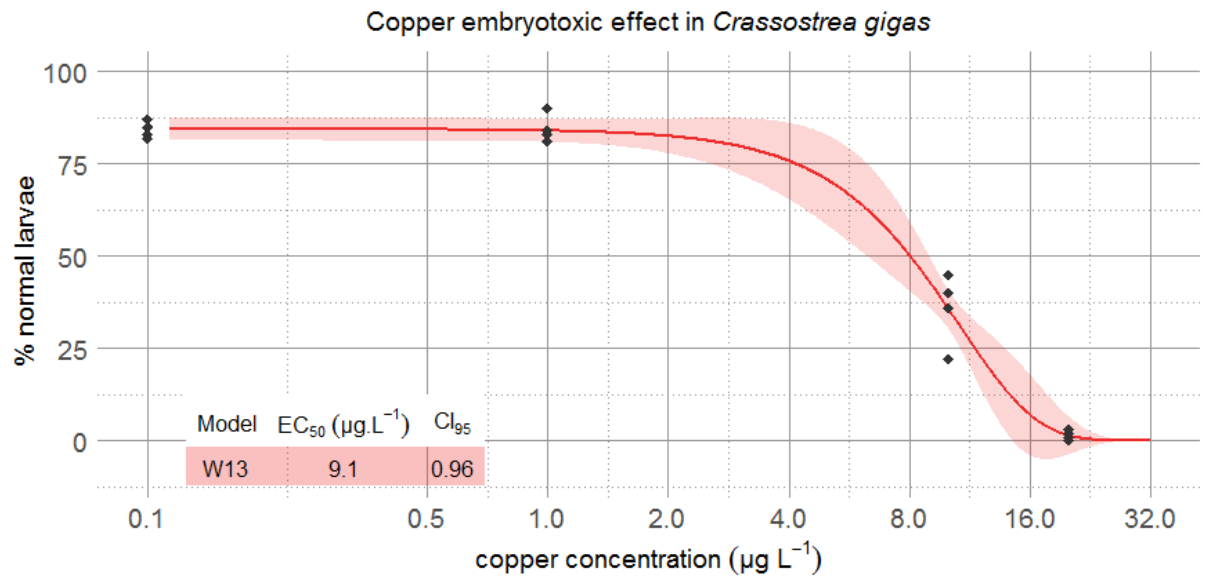

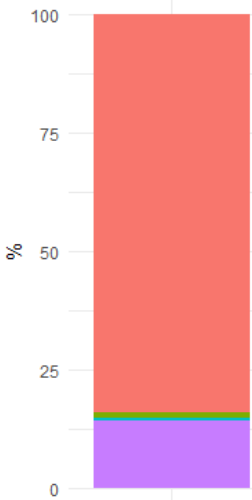

Control

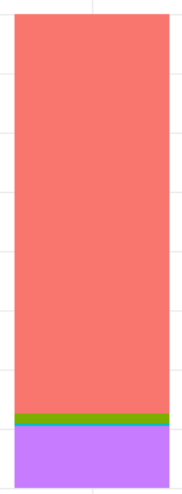

Cu 0.1

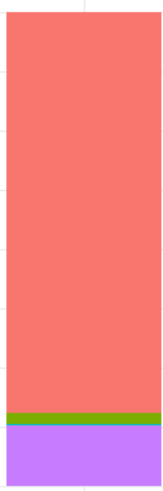

Cu 1

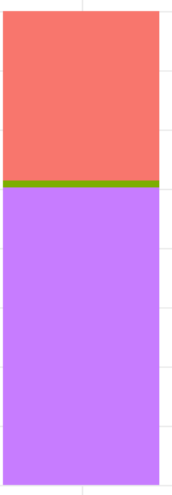

Cu 10

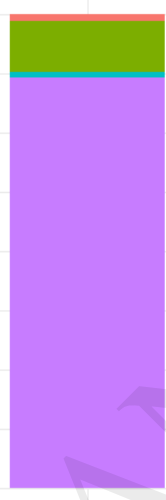

Cu 20

Figure 1.Embryotoxic effect of copper on Crassostrea gigas D-larvae. 1a) percentage of normal shaped D-larvae, significant increase of larval abnormalities is observed from $10 \mu \mathrm{gCu^{2+ }} \mathrm{L}^{-1} ; 1 \mathrm{~b}$ ) abnormality types dependent on copper concentration (expressed as $\mu g . L^{-1}$ ). Data are presented as the mean of 4 biological replicates.

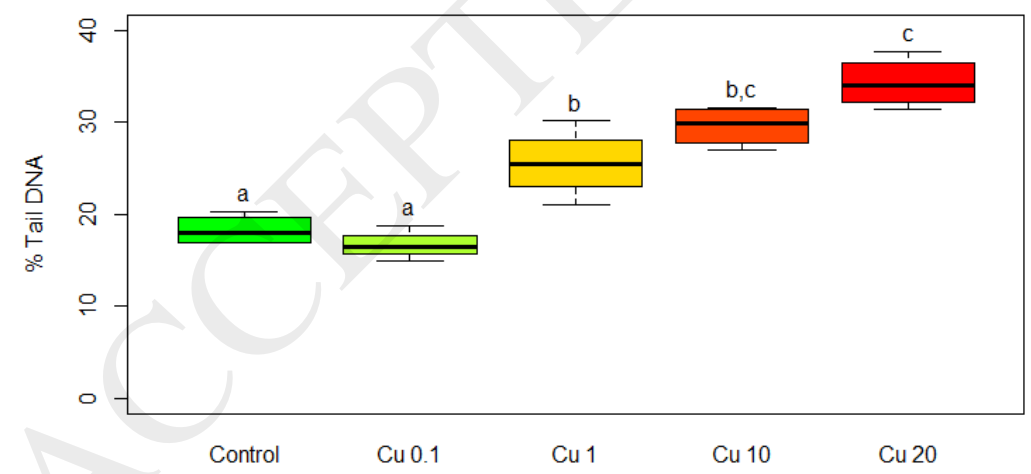

Figure 2. Boxplot of the level of DNA strand breaks measured with the comet test on embryonal cells of Crassotrea gigas gastrula. Significant effects of copper (expressed as $\mu \mathrm{g} \cdot \mathrm{L}^{-1}$ ) toxicity are observed from $1 \mu \mathrm{g} \mathrm{Cu} \mathrm{C}^{2+} . \mathrm{L}^{-1}$. Letters represent statistically different groups calculated by the least significant difference post hoc test $(n=4)$. 


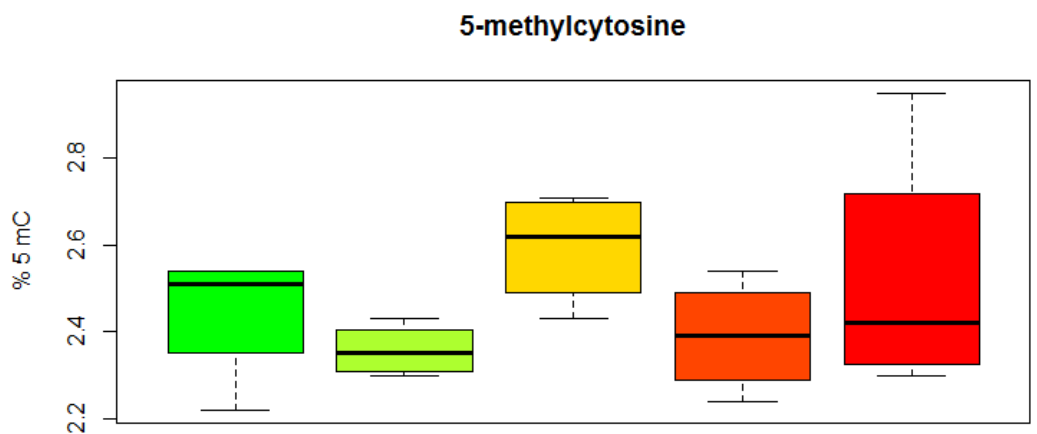

5-hydroxyMethylcytosine

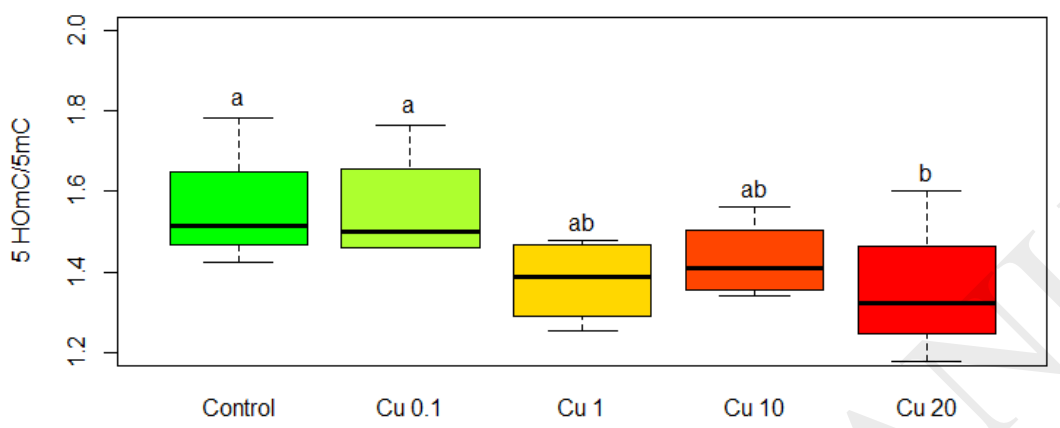

Figure 3. Global DNA methylation, 3a) \% of 5-methylcytosine in whole DNA; 3b) levels of 3-hydroximethylcitosyne (calculated as 5-HOmdC/5-mdC \%), Letters represent statistically different groups calculated by the least significant difference post hoc test $(n=4)$. 


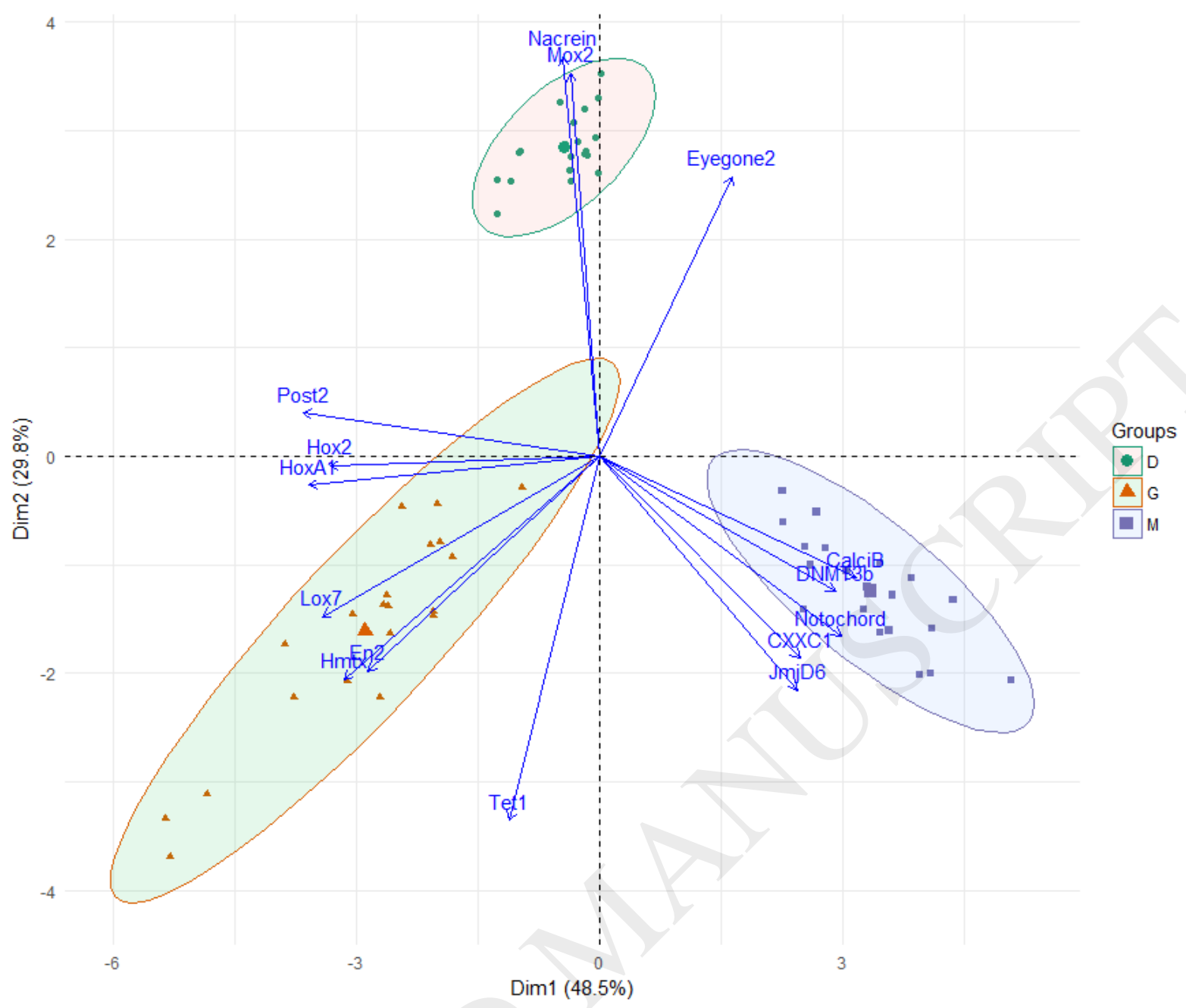

Figure 4. PCA of transcript levels differentiating developmental stages, components 1 and 2 accounted for $48.47 \%$ and $29.76 \%$ of the variance, respectively 

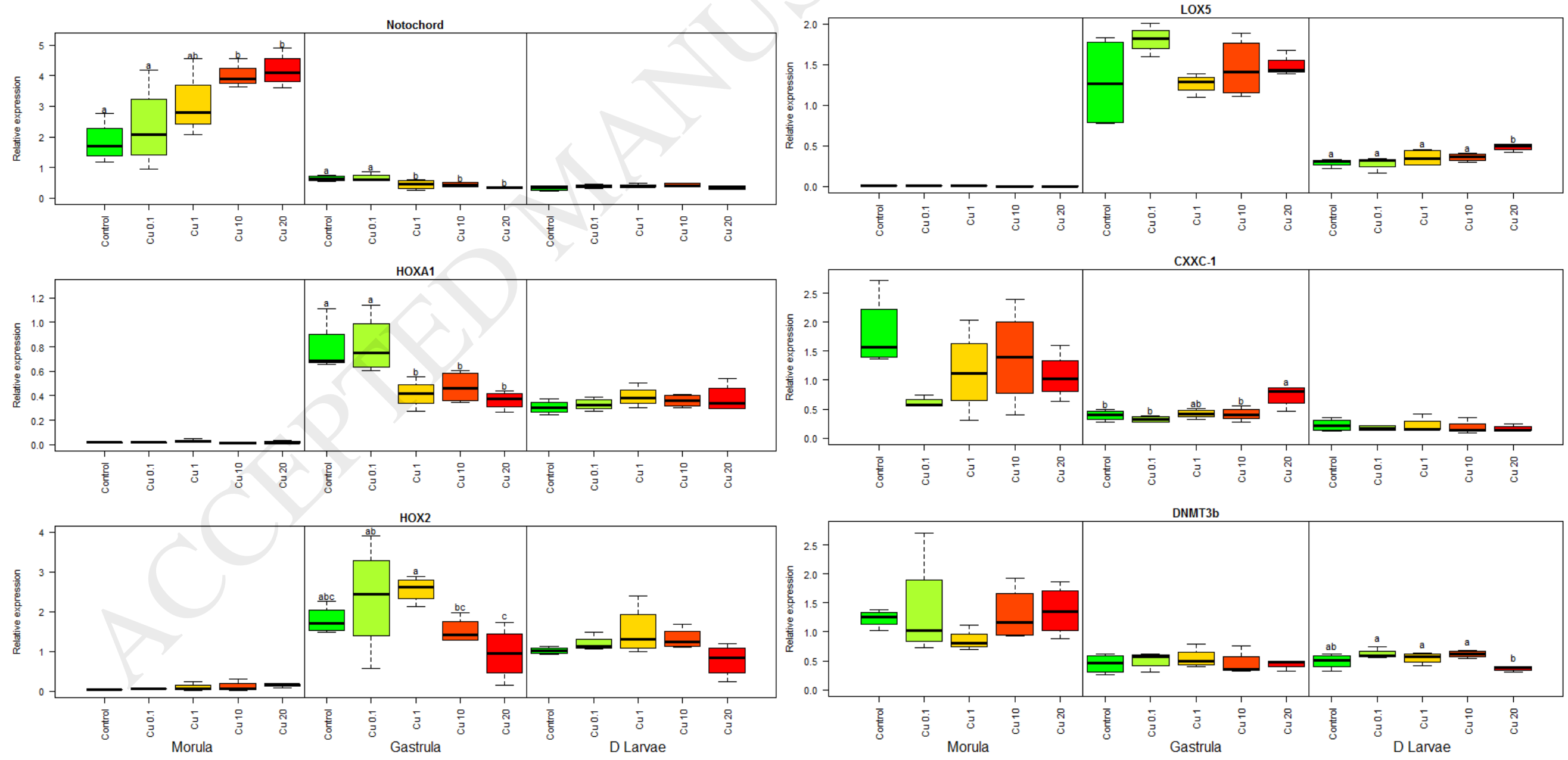

Figure 5.Boxplot of the relative expression of transcripts showing a significant effect upon copper exposure (expressed as $\mu g . L^{-1}$ ) in $C$. gigas embryos. Letters represent statistically different groups calculated by the Kruskal-Wallis rank sum test $(n=4)$. 


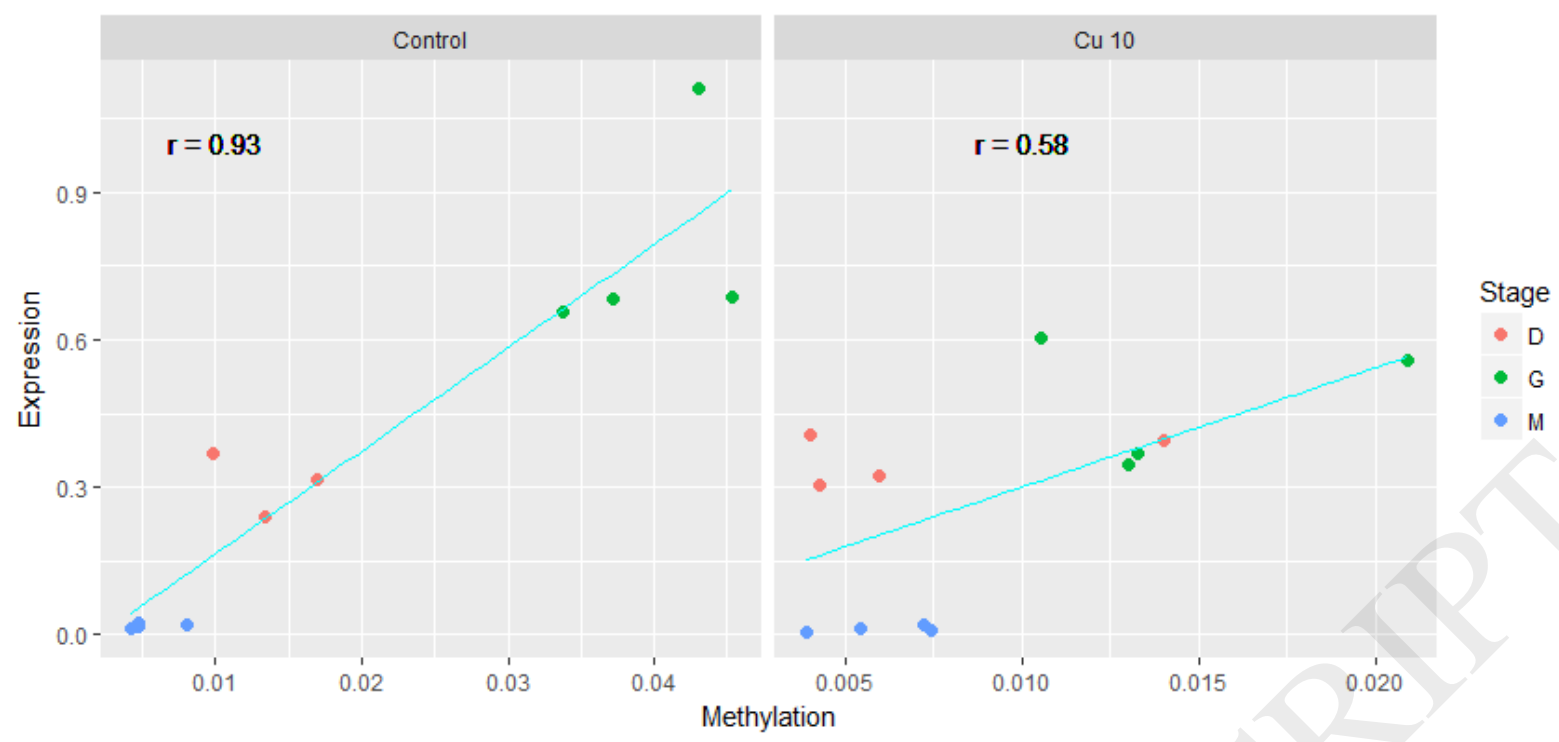

Figure 6. Correlation between the transcript and DNA methylation levels of the first exon of the HOXA1 gene in

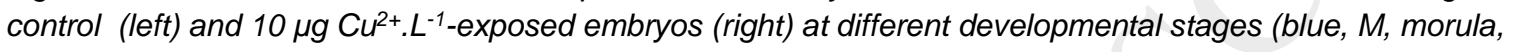
green, $G$, gastrula, red, $D, D$ larvae). The correlation coefficient ( $r$ ) is given. 

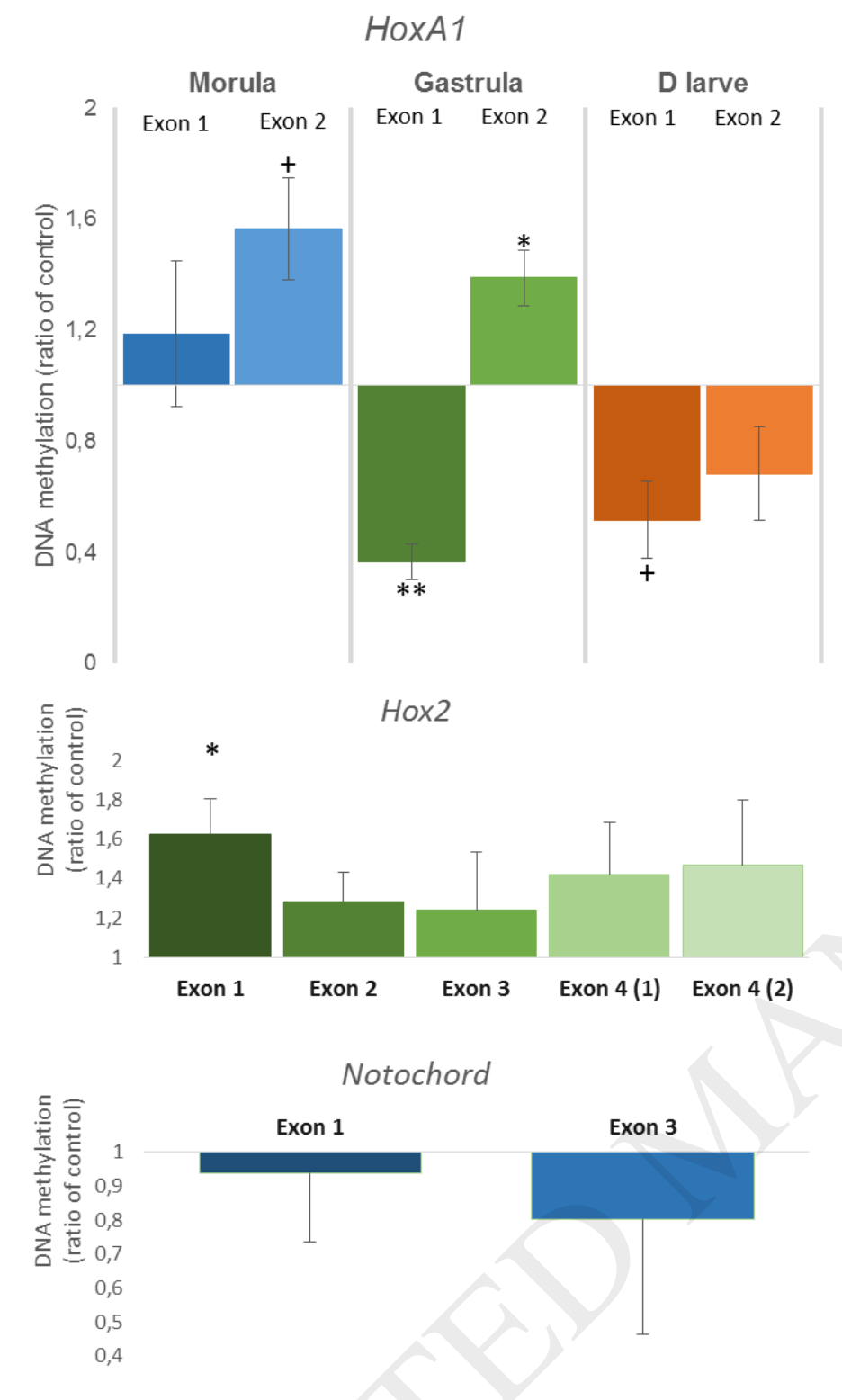

Engrailed2

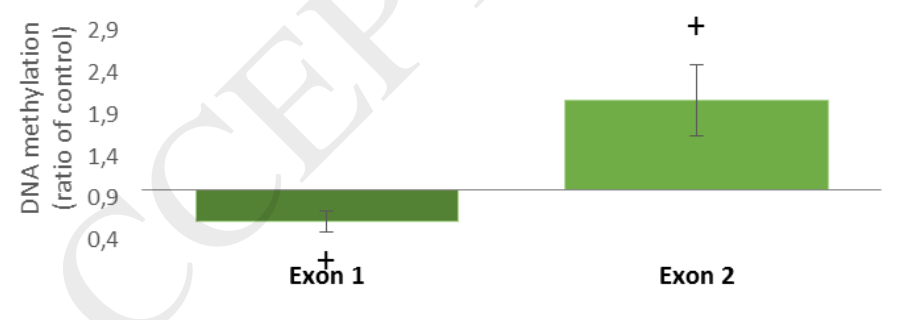

Figure 7.Specific DNA methylation measured by Me-DIP Real-Time PCR. Results are expressed as the ratio of samples exposed to $10 \mu \mathrm{g} \cdot \mathrm{L}^{-1} \mathrm{Cu}^{2+}$ compared to control samples \pm standard deviation $(n=4)$. The methylation levels were measured at the morula (blue, HoxA1, Notochord), gastrula (green, HoxA1, Hox2, Engrailed2) and D-larvae (orange, HoxA1) stages. The exons (or exon regions for Hox2 exon 4) examined for specific methylation are indicated. Significance codes +: $p<0.1 ;{ }^{*}: P<0.05,{ }^{* *} P<0.01$ (two-tailed Student's $T$ test, Welsh's correction was applied when required). 